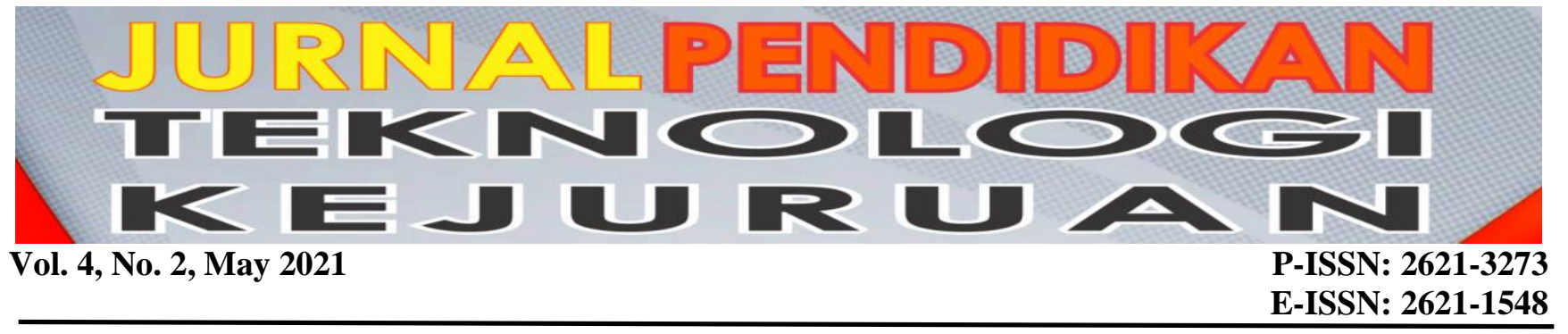

\title{
Aquifer Analysis With Seismic Methods in Parambahan Region
}

\author{
Yaumal Arbi ${ }^{1 *}$, Ari Syaiful Rahman Arifin ${ }^{2}$, Muvi Yandra ${ }^{3}$ \\ ${ }^{123}$ Civil Engineering, Faculty of Engineering, Universitas Negeri Padang \\ "Corresponding author, e-mail: yaumalarbi@ ft.unp.ac.id ${ }^{1}$
}

\begin{abstract}
The problem faced by farmers in Parambahan Region during the dry season is agricultural land does not get adequate water supply from existing irrigation channels, as a result, farmers can only carry out agricultural activities during the rainy season in Parambahan Region Lima Kaum Subdistrict, district of Tanah Datar. This study aims to determine the location and depth of soil layers containing groundwater by using the seismic method, measurements are carried out at two points, with the length of the track at the first point is 80 meters, and at the second point of 70 meters, each measurement on seismic data collection using 4 geophones as signal capture sensors, with a distance between geophones of 5 meters. The results of this study that the wave velocity at the first data point collection was $169.49 \mathrm{~m} / \mathrm{s}$ and the lowest were $87.1 \mathrm{~m} / \mathrm{s}$, and the wave velocity at the second point was $129.68 \mathrm{~m} / \mathrm{s}$ and the lowest was $48.07 \mathrm{~m} / \mathrm{s}$. from the wave velocity, it can be seen the type and depth of the groundwater layer at the point of data collection on the first pass, which is a depth of up to 27.5 meters of the possibility of soft soil and a depth of about 30 to 40 meters of watery soft soil at that depth may have groundwater, and at that point, the second passage at a depth of up to 25 meters is likely to be soft soil and at a depth of around 25 to 35 meters of watery soft soil at that depth, there is groundwater.
\end{abstract}

Keywords: Drought, Seismic, Depth of Soil

\section{INTRODUCTION}

Groundwater has an important role as an irrigation source when surface water from irrigation channels cannot meet or reach agricultural land either due to location constraints or the dry season (Siswoyo et al., 2018). The problem faced by farmers during the dry season is that their agricultural land does not get an adequate supply of irrigation water from existing irrigation channels, as a result, farmers can only carry out agricultural activities during the rainy season

Based on information obtained from the Nagari Parambah headman, various efforts have been made by farmers and the Nagari government in overcoming this problem, one of which is by drilling to obtain groundwater for irrigation. The drilling location error is generally due to the absence of an approach from the scientific aspect to determine the location of drilling points on agricultural land that has adequate groundwater potential. To be able to determine the location of groundwater drilling to obtain adequate potential for irrigation purposes, it is first necessary to investigate the potential of groundwater. One of the ways to investigate the potential of groundwater is by investigating below ground level using a biased seismic method (Listiyani, Nurwidyanto, and Yuliyanto, 2006).

In this study, an investigation of the potential of groundwater in the Parambahan Region uses a seismic method, because one application of this method is to investigate groundwater. The seismic refraction method was used by Listiyani et al (2007) in determining shallow aquifer geometry analysis for a case study of alluvial deposits in the South Dakota area, USA. In addition, there is also Kartika et al (2007) who use the seismic refraction method to determine subsurface structures in Bantul Regency. In data processing, the results of this seismic data recording will use Matlab software.

\section{METHOD}

Research Site

This research was conducted in Parambahan Region, Tanah Datar District. The study was conducted at two points, for each research point obtained two trajectories. The first point is located at coordinates 0 $\circ 27^{\prime} 19.7$ "S and $100^{\circ} 31^{\prime} 56.9^{\prime \prime} \mathrm{E}$, the second location is located at $0^{\circ} 27^{\prime} 15.6$ "S and $100^{\circ} 32^{\prime} 02.7^{\prime \prime} \mathrm{E}$. 


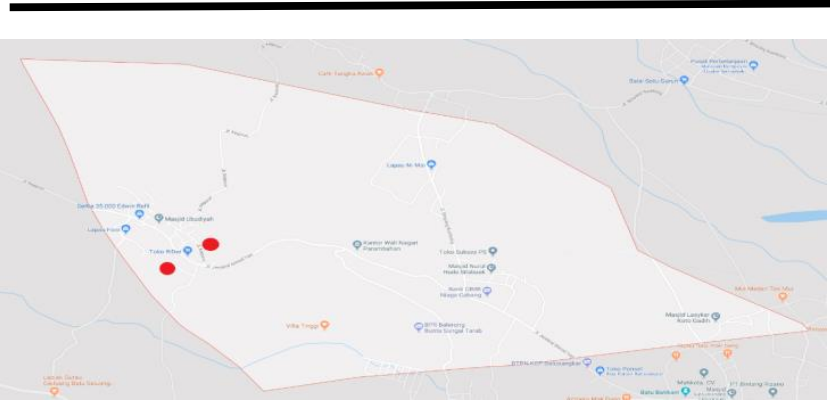

Figure 1. Location research

The research began by seismic data retrieval, as follows:

1. Data is collected by hitting a geological hammer weighing $8 \mathrm{~kg}$ on an iron plate that serves as a source or shoot-point for a track length of 80 meters. The distance of the vibrating source with the first geophone is 5 meters, called near offset.

2. Recording is done by 4 geophones in one straight line with the vibrating source. The space between geophones is 5 meters. The 4 geophones will always move at predetermined points along the 80 -meter path. 3. Placement of the wave source is done to get detailed subsurface structure information. The geophone closest to the source is expected to detect the topmost layer, while the farthest geophone is expected to detect the lowest layer that can be reached.

4. The data obtained from the refraction seismic survey is the travel time of wave propagation from the vibrating source to each geophone called travel time.

Then the seismic data is processed, as follows:

1. Reforming adjusts the format of the field data with the format of the software used. This process is the process of sorting data. The raw data is then formatted into the internal format of the software to be used, which in this practical work uses Matlab software.

2. Cut off signals containing seismic events

3. Retrieve the data of the first wave arriving on each geophone.

4. Normalizing the selected signal. Then the threewave data that has been cut (very small wave amplitude), normalization is done which aims to increase the amplitude of the recorded wave signal

5. Calculate the difference/time difference of waves arriving at each geophone that propagates in the medium (lag time).

6. Filtering is the process of separating the frequency of primary seismic data from the frequency of disturbing primary seismic data. The frequency of the intruder will be removed and destroyed to protect the primary signal.

\section{RESULT AND DISCUSSION}

\section{Seismic Data Recording Results}

Retrieval of seismic refraction data is carried out around the area of the Parambahan region rice field, recording data using as many as 4 geophone sensors recording the signal produced by the punch between the hammer and the iron plate. Data recording is done with one hit between the iron plate and a hammer, recording is repeated over an 80-meter track with a distance of 5 meters from a geophone. The results of recording data every time a blow can be seen in the picture with geophone 1 (black), geophone 2 (magenta), geophone 3 (blue), geophone 4 (red).
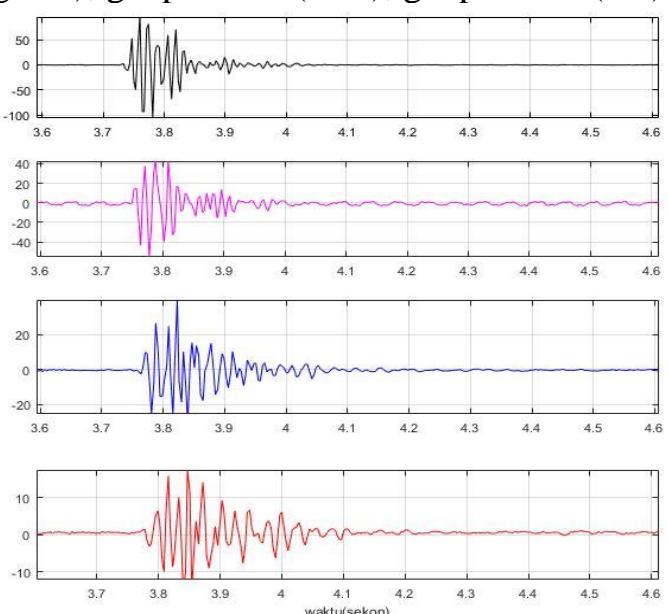

Figure 2. Recording seismic data for the first lane of 5-20 meters
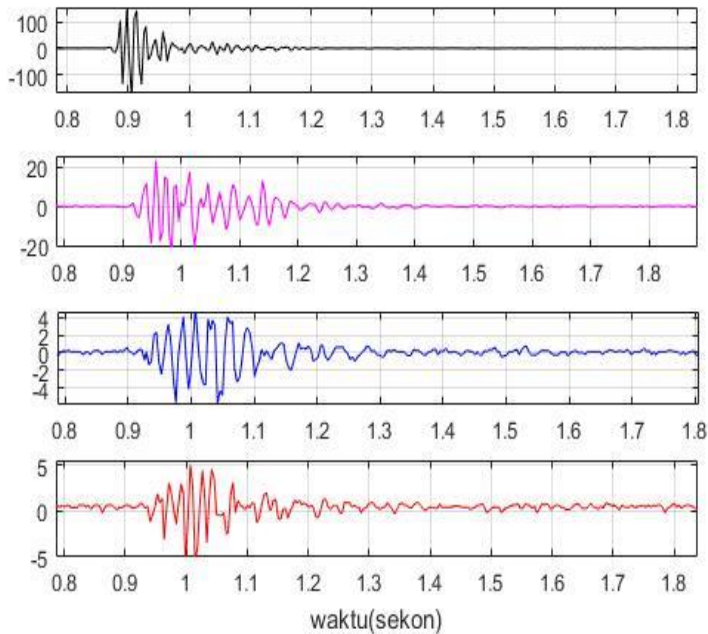

Figure 3. Recording of the first track seismic data of 25 - 35 meters 


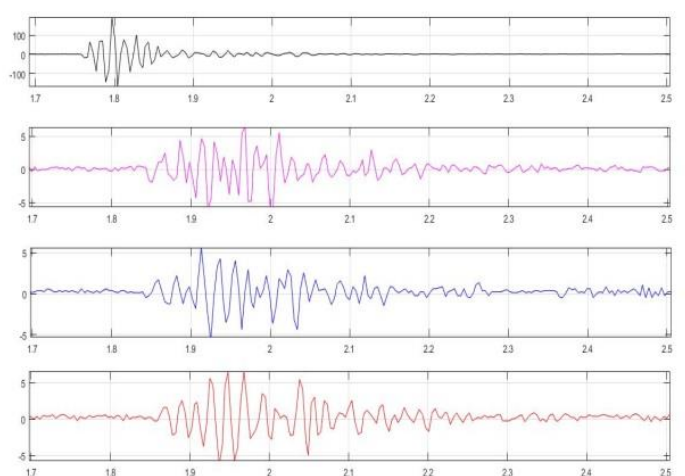

Figure 4. Recording seismic data of the first lane of $40-50$ meters
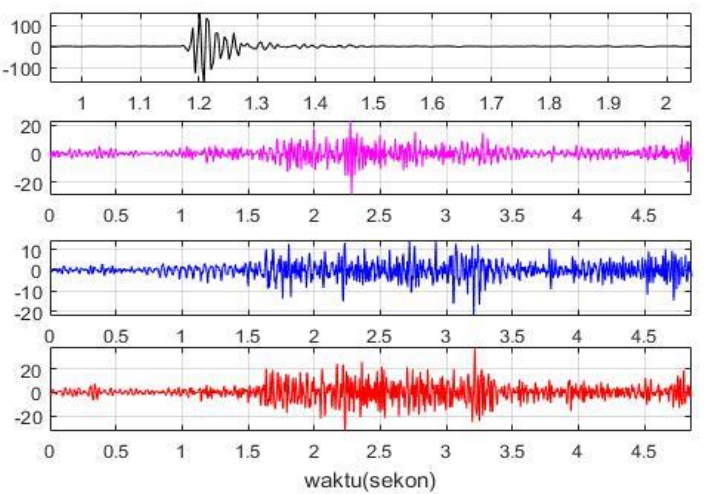

Figure 5. Recording of the first track seismic data of 55 - 65 meters

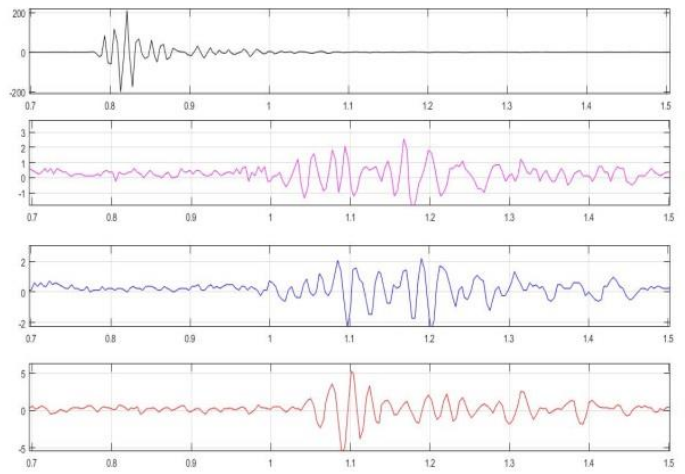

Figure 6. Recording seismic data of the first lane 70-80 meters
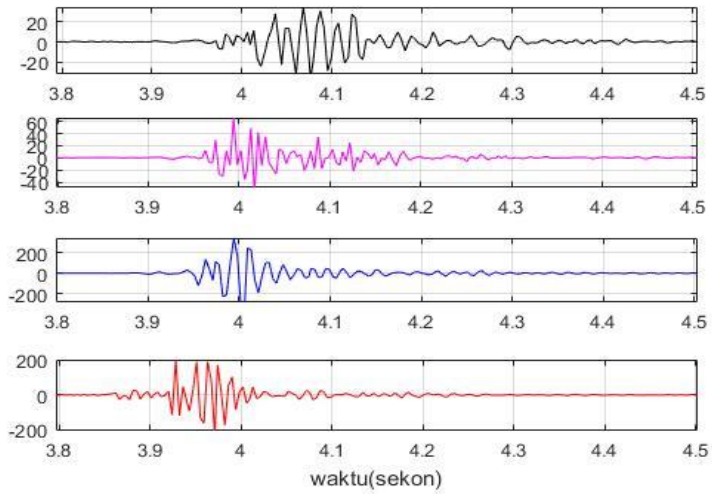

Figure 7. Recording of seismic data of the second track with a distance of 5 - 20 meters
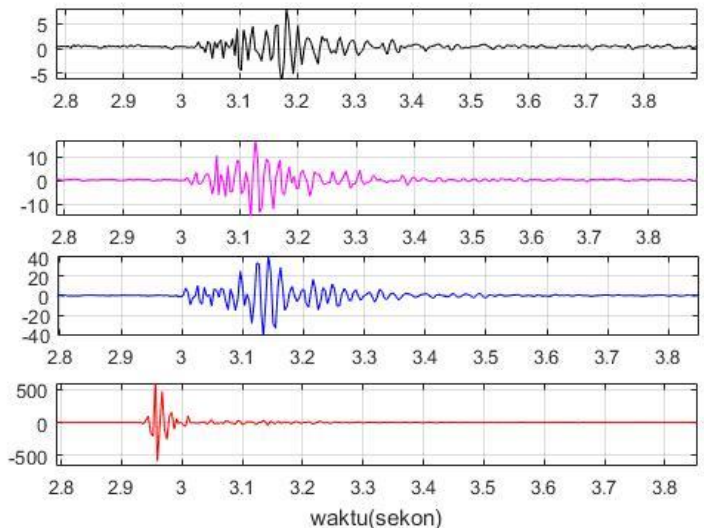

Figure 8. Recording seismic data of the second lane 25 - 35 meters
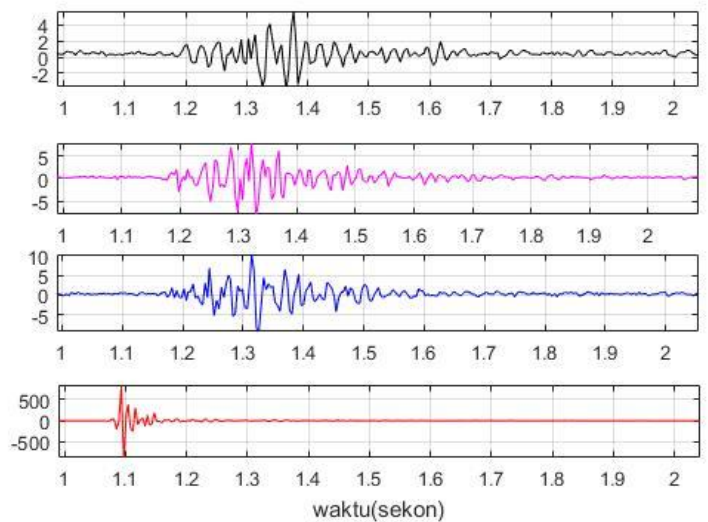

Figure 9. Recording of seismic data of the second track with a distance of 40 - 50 meters

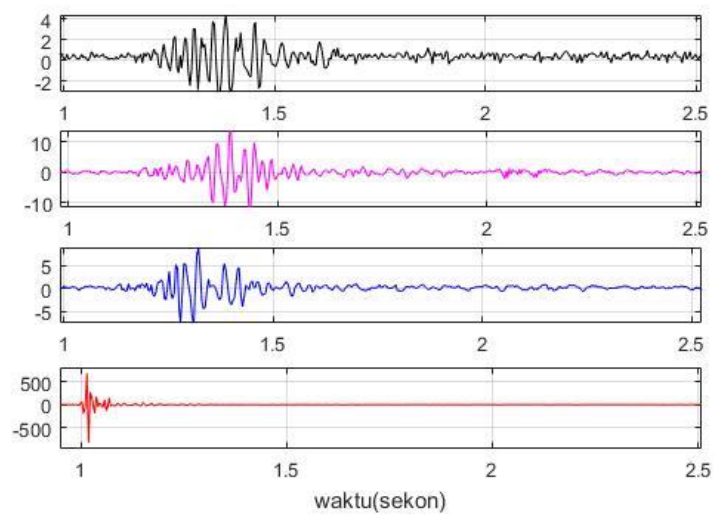

Figure 10. Recording of seismic data for the second track 55-65 meters 

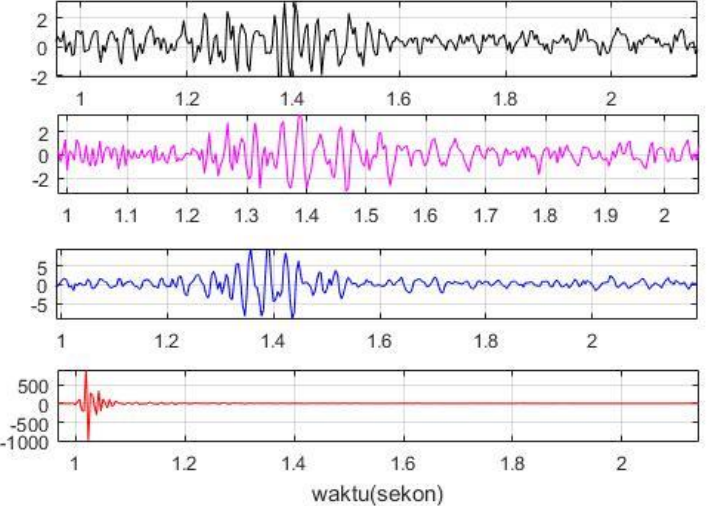

Figure 11. Recording seismic data for the second lane of 6070 meters

1. Cutting and normalization first wave signal arrive Result

Seismic data recorded on the four geophones is only taken as part of the first wave arriving, then the three waves are normalized sequentially Geophones 1 (black), Geophones 2 (magenta), Geophones 3 (blue), Geophones 4 (red) shown in the picture.
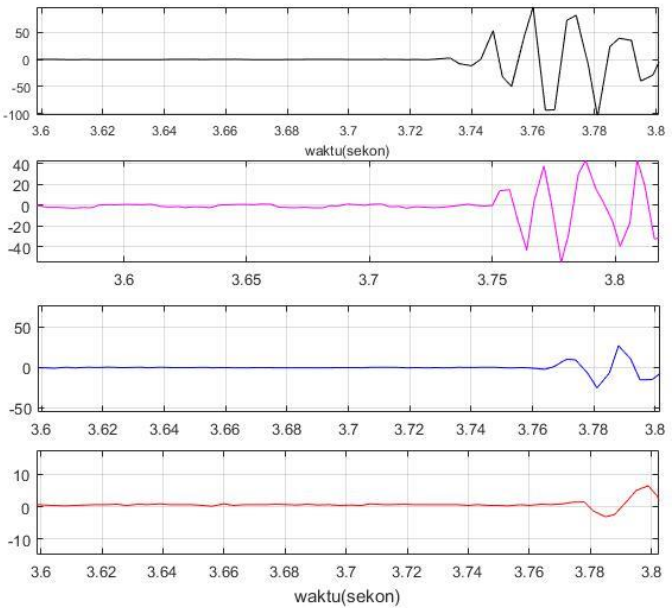

Figure 12. Normalization of the first wave signal arriving

2. Difference time first wave arrives Result

After normalizing and cutting the signal at the first wave, the calculation of the difference in time difference between the incoming waves between G2G1, G3-G1, and G4-G1. From the results of the time difference of the first wave arrived the dominant value of the time interval was obtained, which can be seen in table 1. Based on the dominant value of the table, the travel time curve can be drawn shown in Figure 13.
Table 1. Time of the first wave arrived

\begin{tabular}{|c|c|c|c|c|c|}
\hline Distance(m) & Time(s) & $\mathrm{m} / \mathrm{s}$ & Distance(m) & Time(s) & $\mathrm{m} / \mathrm{s}$ \\
\hline 0 & & & 0 & & \\
\hline 5 & 0,031 & 161,290 & 5 & 0,104 & 48,077 \\
\hline 10 & 0,059 & 169,429 & 10 & 0,16 & 62,5 \\
\hline 15 & 0,132 & 113,636 & 15 & 0,309 & 48,544 \\
\hline 20 & 0,16 & 125,000 & 20 & 0,389 & 51,414 \\
\hline 25 & 0,201 & 124,378 & 25 & 0,226 & 110,619 \\
\hline 30 & 0,319 & 94,044 & 30 & 0,337 & 89,021 \\
\hline 35 & 0,292 & 119,863 & 35 & 0,319 & 109,718 \\
\hline 40 & 0,278 & 143,885 & 40 & 0,337 & 118,694 \\
\hline 45 & 0,333 & 135,135 & 45 & 0,347 & 129,683 \\
\hline 50 & 0,361 & 138,504 & 50 & 0,413 & 121,065 \\
\hline 55 & 0,441 & 124,717 & 55 & 0,67 & 82,090 \\
\hline 60 & 0,684 & 87,719 & 60 & 0,636 & 94,340 \\
\hline 65 & 0,743 & 87,483 & 65 & 0,74 & 87,838 \\
\hline 70 & 0,712 & 98,315 & 70 & 0,781 & 89,629 \\
\hline 75 & 0,861 & 87,108 & 75 & & \\
\hline 80 & & & 80 & & \\
\hline & & & & & \\
\hline
\end{tabular}

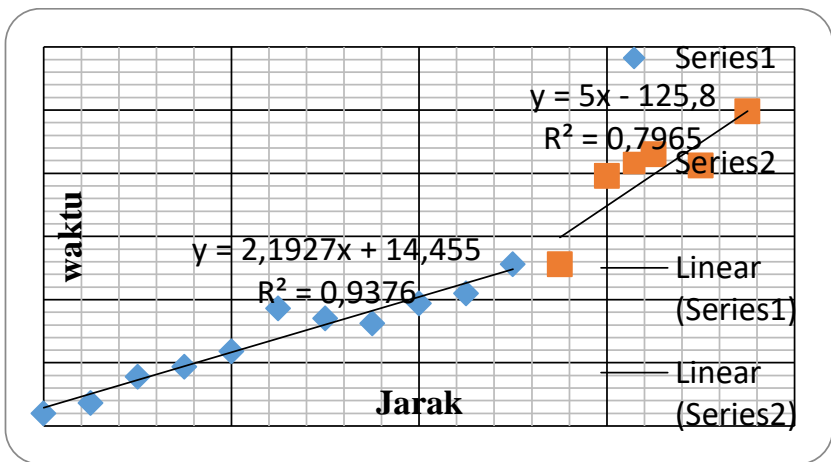

Figure 13 Travel time curve

3. Seismic Data Filter Results.

The dominant frequency in the recording of the signal obtained in seismic data, the filter results are shown in Figure 14.

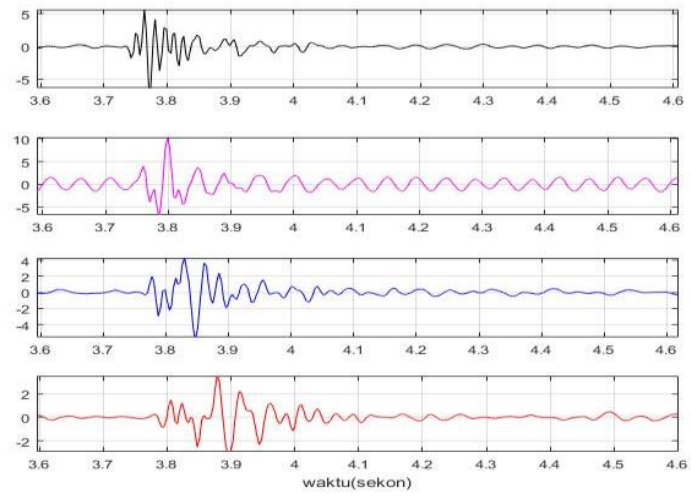

Figure 14. Seismic Data Filter Results 


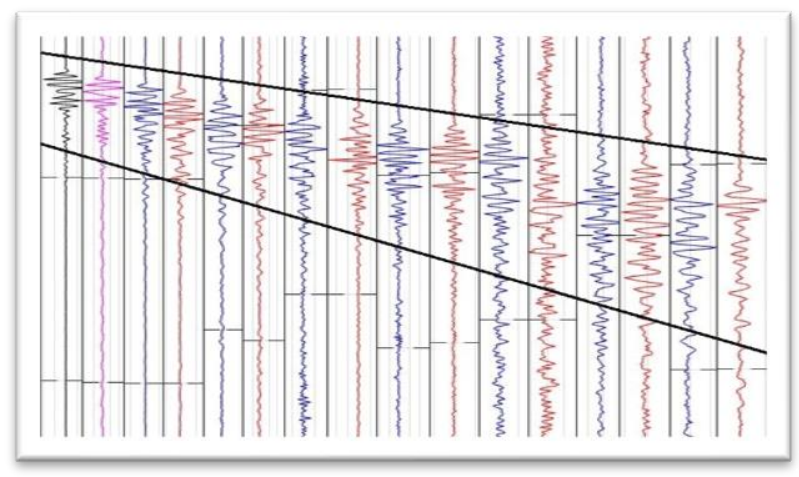

Figure 15. Seismic Data Record

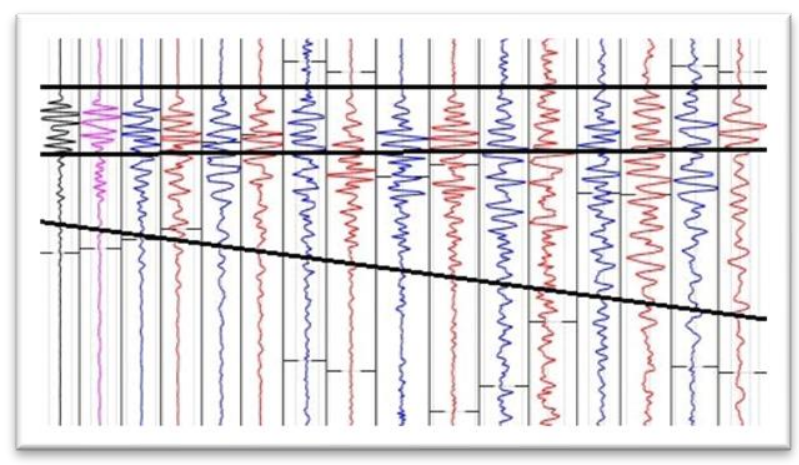

Figure 16. Seismic Data Record

Based on the results of seismic data recording in the field shown in Figure 1, the recording shows the difference in wave time which has a very small size, therefore there is a difference in amplitude in each wave, in seismic data recorded by geophone 1,2,3 and 4-time difference This wave arrival is due to the laying between the geophone, the distance between the geophone as far as 5 meters, where geophone 1 is used as a benchmark for the distance and time the first wave arrives with the geophone 2,3, and 4. Because geophone 1 is the main point of the main, it will not be moved like geophone 2, 3, and 4, then geophone 2, 3, and 4 will be moved to a different place with a distance of 5 meters between other geophones so that it can be seen in Figure 1 and Figure 2 have different distances and times that arrive at geophone 1 and geophone 2 waves, 3 and 4, the more visible until the end of the data collection path.

Seismic data recording is done in paddy fields and many people pass through the location where the seismic data is collected. So that it still occurs (disruption), therefore data processing will begin to be done from signal cuts to avoid inadequate results. Then cross-correlation is performed on the signal.

The results of the cross-correlation there is a different wave arrival time in each geophone, the next activity is to calculate so that it has the result of the $\mathrm{P}$ wave velocity by dividing the distance between the geophone and the difference in the wave arrival time.

The results of the wave velocity can be seen in table 1 . There are velocity results that can be seen in the difference between the wave velocity at the beginning to the end of the path where the data was collected, the highest speed wave is $169.49 \mathrm{~m} / \mathrm{s}$ and the lowest is $87.1 \mathrm{~m} / \mathrm{s}$ in the first trajectory data, while for the second trajectory the highest speed wave is $129.68 \mathrm{~m} /$ $\mathrm{s}$ and the lowest is $48.07 \mathrm{~m} / \mathrm{s}$. With these results, it can be seen that the type of soil at the study site with a speed of $169.442 \mathrm{~m} / \mathrm{s}$ is a type of soft soil at a speed of less than $175 \mathrm{~m} / \mathrm{s}$, which is soft soil. At the lowest speed of $87,108 \mathrm{~m} / \mathrm{s}$, the soil is likely soft and watery. At the location where the data collection is seen the area is an area of rice fields. At a speed of 87,108 m/ $\mathrm{s}$ with a length of 80 meters the depth of 40 meters is known to be possible depths of 30-40 meters where groundwater is present, and at the second trajectory at a depth of up to 25 meters the possibility of soft soil and a depth of about 25 to 35 meters of soft soil runny at such depths there is groundwater.

\section{CONCLUSION}

The speed of wave propagation in the data collection area, with the highest speed of $169.442 \mathrm{~m} / \mathrm{s}$ and the lowest of $87.108 \mathrm{~m} / \mathrm{s}$ in the first track, then the second track obtained the highest speed of 129.683 and the lowest of $48.077 \mathrm{~m} / \mathrm{s}$.

There is the first underground layer soft soil layer as deep as 27.5 meters and aqueous soft soil layer at a depth of 30-40 meters, and at the second trajectory at a depth of up to 25 meters possible soft soil and a depth of about 25 to 35 meters of watery soft soil at depth, there might be groundwater. possibly in those depths, there is groundwater.

\section{REFERENCES}

Hawkins, L. V. 1961. The Reciprocal Method of Routine Shallow Seismic Refraction Investigation.Jurnal Geophysics. Volume XXVI No. 6.

Herlambang, A., 1996, Kualitas AirtanahDangkal di KabupatenBekasi, Tesis: IstitutPertanian Bogor.

Hudha, S. N. et al. (2014) 'Penentuan Struktur Bawah Permukaan Dengan Menggunakan Metode Seismik Refraksi Di Lapangan Panas Bumi Diwak Dan Derekan, Kecamatan Bergas, Kabupaten Semarang', Youngster Physics Journal, 3(3), pp. 263-268.

Jongmans, Denis. \& Garambois, Stephane. 2007. Geophysical Investigation of Landslides. Bulletin Societe Geologique de France 178, 2. Hal-00196268. Juanita,

Retno.2011.http://juanita.blog.uns.ac.id/files/2011/01/ 
gelombangseismik1. pdf.

Krussman, G.P. and Ridder, N.A., 1970. Analysis and Evaluation of Pumping Test Data. International Institute for Land Reclamation and Improvement, Wageningen

Nurdiyanto, B. Drajat, N. Sunardi, B. DanSusilanto, P. (2011), Penentuan Tingkat Kekerasan BatuanMenggunakan Metode Seismik Refraksi, Jurnal Meteorologi Dan Geofisika Vol. 12 No. 3, Desember 2011:211- 220.

Priyantari, N. \& Suprianto, A. 2009. Penentuan Kedalaman BedrockMenggunakan Metode Seismik Refraksi di Desa Kemuning Lor Kecamatan Arjasa Kabupaten Jember, Jurnal ILMU DASAR Vol. 10 No.1 . 2009: 6- 12 .

Rucker, M.L. 2006. Integrating Seismic Refraction And Surface Wave Data Collection And Interpretation For Geotechnical Site Characterization. Geophysics Conference, St. Louis, Missouri, USA.

Siswoyo, H. et al. (2018) 'Penyelidikan Potensi Air Tanah Pada Lahan Pertanian Di Desa Bono Kecamatan Pakel Kabupaten Tulungagung Dengan Menggunakan Metode Potensial Diri', DINAMIKA REKAYASA, 14(2), pp. 112-118.

Susilawati. 2004. Seismikrefraksi (dasarteoridanakuisisi data), USU Digital Library.

Taib, M. I. T. 2000. SeismikRefraksi. Bandung. InstitutTekhnologi Bandung Press.

Tipler, Paul. A; alih bahasa, Bambang Soegijono; editor, Wibi Hardani. 2001. Fisika Untuk Sains Dan Teknik. Jakarta: Erlangga.

Todd, D.K. dan Mays, L.W. 2005.Groundwater Hydrology (Third Edition). John Wiley and Sons, In. New York.

Y. Arbi, R. leonardo Siregar, and Tri Padmi Damanhuri, "KAJIAN PENCEMARAN AIR TANAH OLEH LINDI DI SEKITAR AIR DINGIN KOTA PADANG," Sains dan Teknol. J. Keilmuan dan Apl. Teknol. Ind., vol. 18, no. 1, pp. 46-52, 2018.

Y. Arbi and E. R. Aidha, "SIMULATION OF MERCURY TRANSPORT FROM GOLD MINING ACTIVITIES IN PELAWAN RIVER SAROLANGUN," in 4th International Conference on Technical and Vocation Education and Training, 2017, vol. 4, pp. 567-571. 